quiet medical existence had turned into total clinical chaos. My worst fears were confirmed. Tony was dead, such a good friend, too, but there was nothing that could be done for him now. We buried him where he lay, wrapped in our flag, and with a dignity that his family would welcome. The problem was now the survivors. Brummy's cervical spine and Graham's frostbite were no trouble. They were both conscious and mobile and, though I had no way of knowing if Brummy's neurological changes were indicative of an unstable fracture, he was at least capable of walking. No, the main worry was Andy. I was stuck with a semiconscious, immobile patient at almost 20000 feet. For a healthy man, base camp, and the road, was six hours' arduous walk away; the stretcher had been broken but the weather was good. Andy owes his life to his own strength and the help of his team mates who carried him down, semicomatose, on an undamaged crevasse ladder. It was four days from injury before we reached base camp during which time he had had a respiratory arrest, frequent cyanotic attacks, and inhalation of vomit. I cannot pretend that evacuations of that nature ever go smoothly, but he is alive, albeit battered, and will most likely climb again. From base camp he, and the other injured fellows, would have to return home, while the remainder of the team would stay and salvage what they could.

The journey home was an epic one. Our Tibetan driver became somewhat alarmed at the prospect of carrying three injured men, his concentration wavered, and our jeep ran off the road. We were not impressed and were fortunate not to damage ourselves further. For the next five days we jolted across the land, stopping at villages to beg $x$ ray facilities and being obliged to use machines so primitive that even now my gonads are humming with the quantity of radiation that they have probably received. It was not until we reached Hong Kong, nine days after injury, that an effective $x$ ray supported diagnosis was made.

I am home now and the expedition is over, for not only did we lose four good climbers but all our equipment as well. Despite the tragedy, I will have fond memories of Everest and my determination to succeed next time will be stronger than before. Tony is the reason, at least part of the reason, that I think that we would like to return. Often he would sit in our private little valley and philosophise on why he was there. I remember him saying, despite the challenge, that he wanted to reach home alive. He would not forgive us if we did not return and so, if you are going, I will come.

\title{
Six months on a slow boat to China
}

\author{
NICHOLAS HOLLIS
}

20 June-South China Sea. The ship lurched again and I rolled to the edge of my canvas bunk; not so far as to fall out, but enough to break the false security of the half sleep in which I was trying to escape our grim situation. We knew that if she rolled over a few more degrees the gear and ballast could shift and then she would keel right over and sink. It was raining steadily, and with the hatch covers down the atmosphere below was fetid from the crew's bodies, wet clothes, ropes, food, and things rotting in the bilges. For five days now we had been alternately running downwind and lying ahull during squalls that had ripped most of our sails to shreds. There was a threat of a typhoon, and as I lay below off watch my thoughts went back and I wondered about the chances of ending up as shark meat after all.

My thoughts had gone back six months to December, when I had been in the warmth and security of a London operating theatre. My surgical colleague had jokingly asked if I was interested in sailing on a mediaeval dhow from Oman to China and had added that it might be good fun if we didn't end up as shark meat. Within four weeks I had given up administering anaesthetics under the 40 watt English winter daylight and was looking after my new patients and shipmates in the dazzling brightness of Sri Lanka. Happily, the sharks ended up as meat for us and not the other way round.

\section{The dhow}

Sohar was a 97 foot boom dhow built in Oman the previous year. Superficially she looked much like many other large dhows; the crucial difference was that she had no engine and there were no bolts or nails used in her construction. Her timbers were fastened with 400 miles of coconut fibre rope, each plank being stitched to its fellow. It was a technique of construction used by Arabs in the eighth

Westminster Hospital, London SW1

NICHOLAS HOLLIS, FFARCS, locum senior registrar

Correspondence to: 3 Hamilton Drive, Melton Mowbray, Leicestershire, LE13 0QY. century, but from the time of the Portuguese it was neglected on larger vessels in favour of iron nails. It is said that the Arabs believed that there was a great magnet in the sea that would draw the nails out of a ship's timbers. The sewn part of the construction was one of the largest unknowns, but it turned out to be watertight as well as flexible. Perhaps surprisingly, a sewn ship had a much longer life than a nailed one, in which the nails have to be replaced every few years because of rusting.

\section{The crew}

Sohar was so named after a sea town in Oman which in the eighth to the tenth century was the centre of a large Omani seaborne empire extending from Zanzibar to China. The tales of Sindbad's voyages probably originate from yarns of seafarers of those times, and the town of Sohar was reputed to have been Sindbad's birthplace. It was to retrace the stories of the Sindbad legend along the spice trade route to China that Tim Severin, the project leader, built Sohar with generous support from the Omani government. Sohar left Oman in November 1980 with a crew of eight Omanis, a Baluchi cook, an Indian shipwright, and an assortment of 11 Europeans: Tim Severin the captain, marine biologists, a photographic team, and divers, but at that stage no doctor. The ship arrived in Sri Lanka-the Arabs' "Serendeeb" or serendipity-in January. The constant potential for serious injury with the heavy blocks and spars and a bone deep gash in the foot of Peter Dobbs, our diver, emphasised the need for a doctor on board before the longer and more arduous legs of the voyage.

I found myself in sharp contrast to the dark skinned and piratical looking crew dressed largely in loincloths. I think the Omanis had expected their new doctor to wear a white tropical uniform, keep his hands clean, and hold formal surgeries. It might have made the Omanis hold my medical skills in greater esteem if I had done so, for it was a surprise to them to see their doctor wearing a lungi and pulling on the ropes alongside them.

The Omanis were all good seafarers, most of them having a recent sailing heritage. Several had been on trips to Africa as boys before the dhow trade ceased. One, Juma, a man of indefinite age, was a 


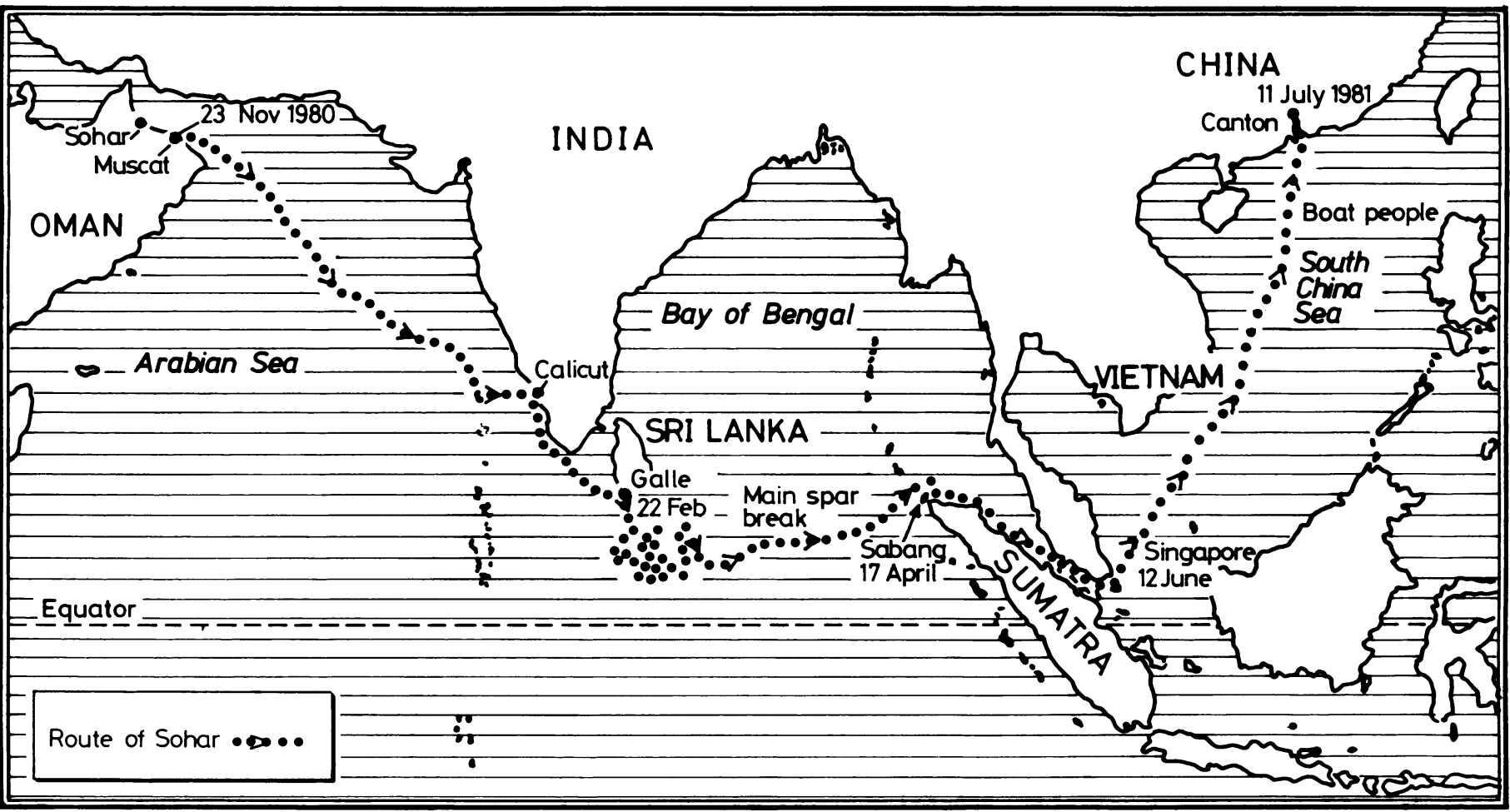

The route taken by Sohar from Oman to Canton.

sailor of many years' experience and had made several trips to Africa. He was one of my watchmates and I could see that he had the hallmarks of a professional seaman. While on the helm he could light a cigarette in a stiff breeze and still keep on course and, though he never did a thing more than he had to, he was often to be found at the fore when sails and rigging were out of hand.

The Omanis were interesting people. Sometimes they could be amazingly tough and bravely withstand pain from an injury while at other times they would make much of just a rumbly tummy. Language was not a problem as we had a couple of interpreters and soon a lingua franca of "boat Arabic" developed. They had some interesting home cures for sprains and bumps. One was a poultice made from dates, curry powder, and garlic, which was applied firmly to the affected part for a day or so. Symptoms of tobacco deficiency were common and varied but easily recognised. The only smoker who was anything like correct in his own rationing of cigarettes for the eight week passage from Sri Lanka to Sumatra was Ibrahim, our cook. His Indian caution would have seen him through, but considerable pressure led him to share his supply with his prodigal peers. Despite this public spirited gesture, the Omanis' hubble bubble soon had our best Earl Grey tea leaves smouldering inside it. The smoke was neither relaxing nor hallucinatory.

\section{My duties}

My first duty in port was to try to improve the smell from the bilges. It sounded a humble and unfitting task, but my scientific background and concern for the public health of the crew made me the natural choice for the job. The problem was the smell of bad eggs from hydrogen sulphide, the product of a foul ferment between bacteria in the sea water and the vegetable oil used to protect the vital coconut stitching. That we could smell the gas at all meant that it was below the lethal concentration, but any silver item taken below decks would tarnish black in a matter of hours, and we wondered what long term effects chronic exposure to small amounts of the gas might have on us. A detergent used to wash out the bilges might have destroyed the oil's protective effect on the coconut fibres, which was an unacceptable risk, so I had to find a bland bacteriocide that was not a detergent. At length I got hold of some chlorhexidine in aqueous solution that was added to the bilges after they had been washed through with fresh water. It did no good, and we had to live with the smell all the way to China. Not surprisingly, we slept on deck unless it was pouring with rain.

\section{The route}

From Sri Lanka to Sumatra was to be the most interesting, frustrating, and varied leg of the voyage. Setting off in February in a fresh north east monsoon, we soon found that our headway east was limited by our poor ability to make effective ground to windward, compounded by a steady countercurrent that took us back whenever the wind dropped. We worked south to within two degrees of the equator when the winds became variable and dropped - for about a month. It became a trying time. We busied ourselves with the normally choresome maintenance and sorting of stores, many books were read, and various canvas garments and bags were made from

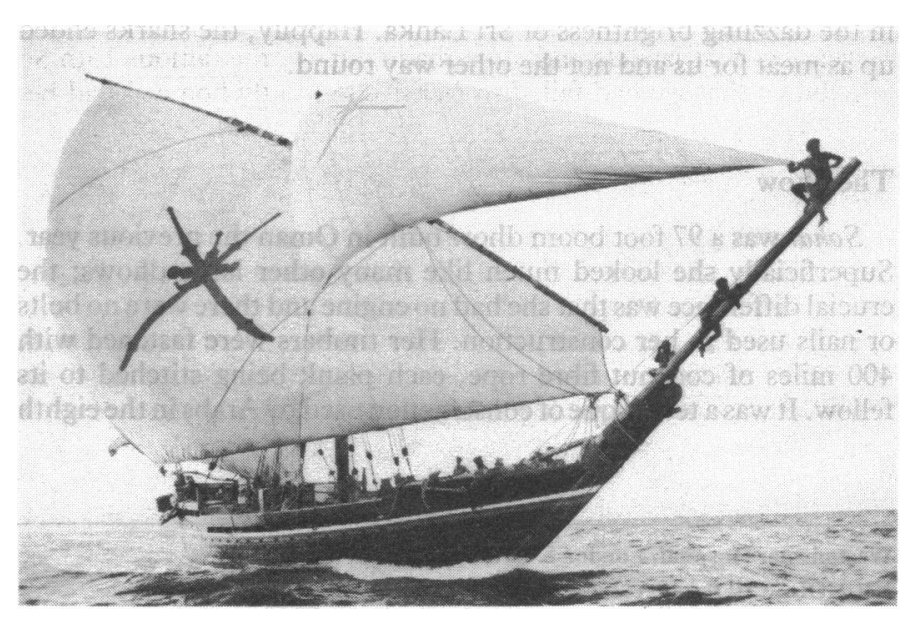

The Sohar-the replica of the ninth century Arab trading vessel in the open seas. 
spare sailcloth. The nights were long and starlit, and I became interested in astronomy and astronavigation, both ancient Arabic and modern. In the meantime the stores were being eaten up, the water tanks were emptying, and morale was becoming low. We were just waiting-waiting for the wind. People retreated into psychologically safe cocoons, mostly avoiding any subject that might lead to argument, and particularly avoiding the subject that was foremost in our minds-when the south west monsoon would come. The pace of life descended to an incredibly slow routine, the Omanis coping well with their catlike ability to sleep when there was nothing to do. By contrast my diary for the period also tells of magical nights sleeping on deck in a hammock, of treating Ibrahim's tropical ulcer, which gradually healed week by week, of rewiring the radio set, and

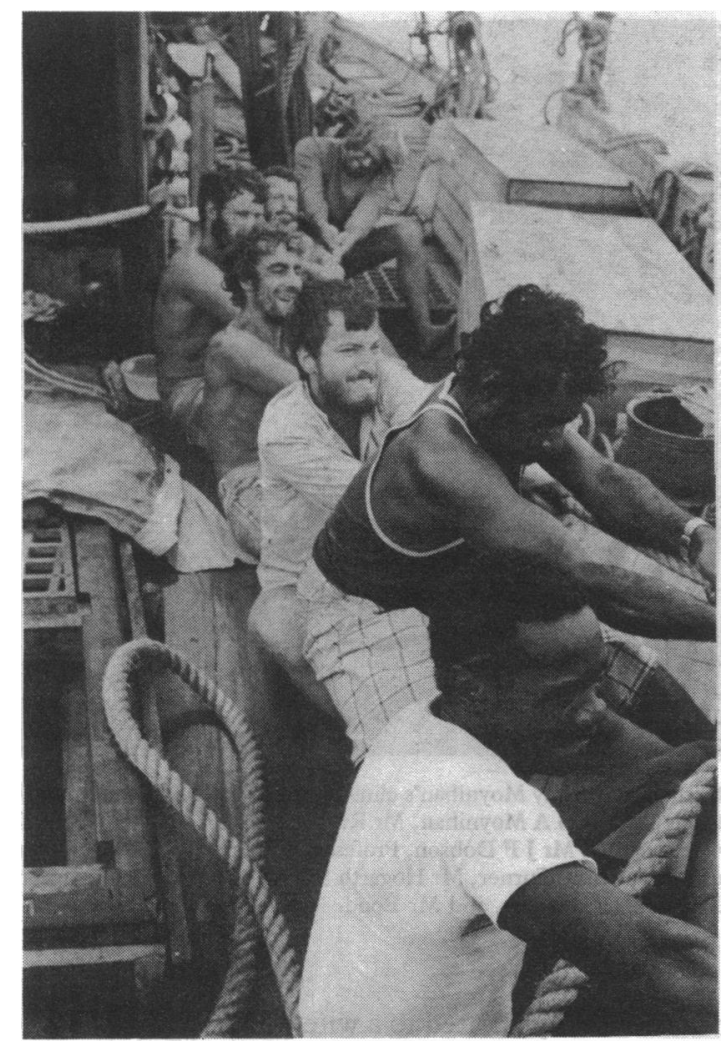

Pulling in the main sheet.

of a shark buzzing Peter Dobbs while he was over the side working on the damaged rudder. Our staple diet was two chapatis for breakfast, a main meal based on rice at lunch, and the same at supper, all cooked over an open charcoal fire. Eggs we stored greased in soft paraffin, and they kept extremely well despite the heat. Later on we caught fish, which were delicious grilled, but the best treat was the several huge sacks of dates in the hold, a complete food which stored well and of which we never tired.

About a week before the south west monsoon started, the Omanis suddenly landed 17 sharks in a mad frenzy, which was just as much on deck as in the water. The incident acted as a release for the tension that had built up over the preceding weeks and we now had a large amount of meat to eat, though I could recommend it only if one were very hungry. Before long we were making good progress under a following wind that brought rainwater to drink and wash with. One night while we were pushing along at good speed the mainsail became back winded and the $75 \mathrm{ft}$ main spar broke in two and came crashing down. Fortunately the wind was now so strong that we made good progress to Sumatra under jury rig, arriving there 57 days after leaving Sri Lanka.

Sumatra was probably where Sindbad's Old Man of the Sea took the form of an orangutan. The latest admiralty pilot described the natives and chief of the island of Pulau Wé as friendly and we found them so, but they were much more interested in Pepsi Cola and Hondas than mirrors and beads. They showed us where we could fell a tree suitable for replacing the broken section of our mainspar and it served us very well.

From Singapore to Canton was about 1500 miles which was completed in just three weeks-stark contrast to our progress on earlier legs. I shall never forget the exhilaration of taking the helm at night with the great ship powering ahead, sometimes as fast as nine knots, with nearly 3000 feet of canvas aloft. Making good time was of the essence, for each week that went by increased the chances of being caught by a typhoon, and the anxious time in heavy weather described at the beginning was on this leg, only a week after leaving Singapore. Before reaching China we came across a lone motor vessel on the horizon coming towards us. Ever aware of the danger of piracy, our yeomen prepared arms and lowered a boat to reconnoitre. Far from being pirates they were 16 Vietnamese boat people, including several children and babies. They said they were eight days out from near Saigon bound for Taiwan, and they seemed uncertain of their direction. Their compass card was an old United States Air Force relic that was half floating in a bath of diesel fuel. We thought that they must have left in a hurry for they had few possessions with them and little clothing. I thought that they looked in a reasonable physical state and they gladly accepted food, tobacco, and clean drinking water. With good weather and luck I suppose they had a good chance of making a safe landfall. We were all moved by their pathetic plight and the thought of the hundreds of others that perish on their way to freedom each year, victims of storms, sharks, and pirates.

\section{Journey's end}

Sohar's official arrival in Canton was a grand affair with bands, firecrackers, and singing children. It was a magnificent welcome for us by the people of Canton. We were representatives for the people of Oman, whose ruler had in part sent us on an international voyage of goodwill in celebration of Oman's 10th year as a modern state. We had relived the epic voyages of Omani sailors of over 1000 years ago and reaffirmed the bonds of history between two ancient peoples. Sohar had sailed 6000 miles in eight months, a true slow boat to China. The lucky crew had now to disperse, but we all share memories of comradeship in a unique experience.

Months later I saw the advertisement for my former job on Sohar in an old copy of the $B M \mathcal{F}$, the Christmas edition for 1980: "Doctor needed January to July on voyage from India to China . . . Sailing experience useful." Nowadays I always read the back pages of the $B M \mathcal{F}$.

\section{An exploding haggis}

A housewife placed a haggis in her electric oven at $160^{\circ} \mathrm{C}$ for an hour. On removal it exploded causing second degree burns to her face. The rest of the "wee beastie" was splattered over the kitchen walls and ceiling. Haggis meat is contained in either a plastic skin or in a genuine cooked sheep's stomach. Only plastic skins explode, according to my local butchers. They recommend a small cut or a few pricks in the plastic skin before cooking to release steam and juices. Perhaps a warning should be issued when a plastic covered haggis is sold.-IAN CROWTHER, general practitioner, Dunblane.

The BMF's cookery editor assures us that there is an even safer method of dealing with aggressive haggis puddings. Remove the beast from its skin, cut into pieces, mix with sautéed onion, and place in a greased dish in a moderate oven for one hour. Purists may baulk, but the result causes the rest of us fewer problems with dysphagia and reflux.-ED, $B M \mathcal{F}$. 